\title{
latrogenic foreign body in an adult with presbyacusis
}

\author{
Hannah Louise Morley
}

Department of Otolaryngology, Lister Hospital, Stevenage, UK

\section{Correspondence to}

Hannah Louise Morley, hannah.morley1@nhs.net

Accepted 20 December 2017

\section{DESCRIPTION}

Foreign bodies in the external auditory meatus are a common presentation to Otolaryngology both to clinic and as an emergency. ${ }^{1}$ Most objects referred to Otolaryngology are round and hard such as beads and are more difficult to remove. ${ }^{1}$ While many patients are aware of what might be in their ear, some do not. The causative event can be missed, and the symptoms can be non-specific. ${ }^{2}$ They may present with a foreign body sensation, a feeling of fullness in the ear, otalgia and recurrent otitis externa. Many of these symptoms can be applied to a presentation of impacted cerumen.

These images refer to a 67-year-old man who presented to Otolaryngology having been referred by his General Practitioner. On presentation to the clinic, he had persistent otalgia in the left ear and reduced hearing for the past 3 months. He also described a feeling of fullness in the left ear.

On examination with an otoscope, there was thick cerumen present. The cerumen was difficult to remove so he was sent away to use olive oil eardrops for 1 week and return to the Acute Clinic for further assessment.

On the second presentation to the clinic, a large amount of cerumen was removed from the left ear using microsuction. This gave the patient some slight symptomatic relief; however, his hearing was not at his baseline level. He later returned to the clinic for a third time still being symptomatic

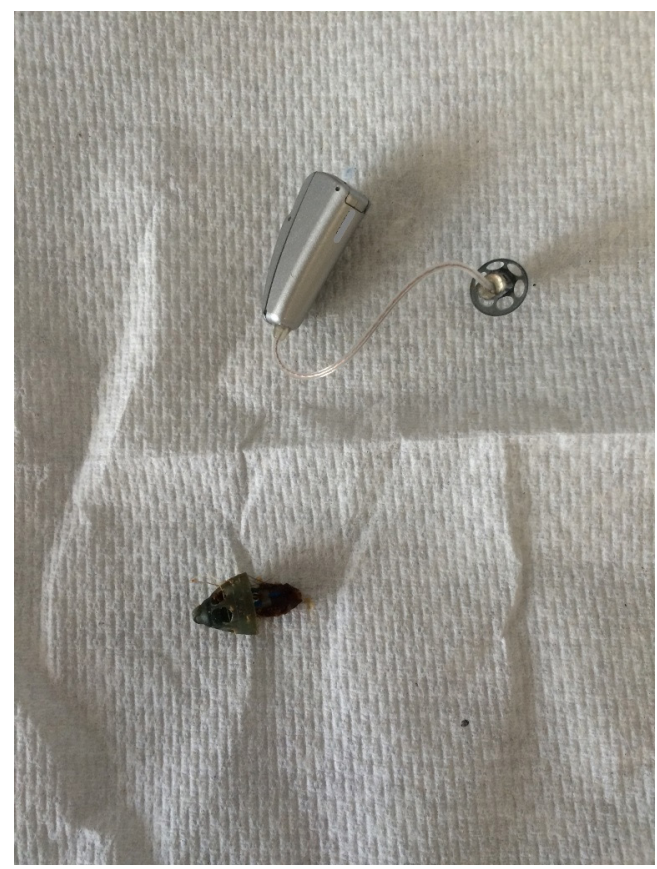

Figure 1 Foreign body removed from the external ear canal alongside the original hearing aid mount.

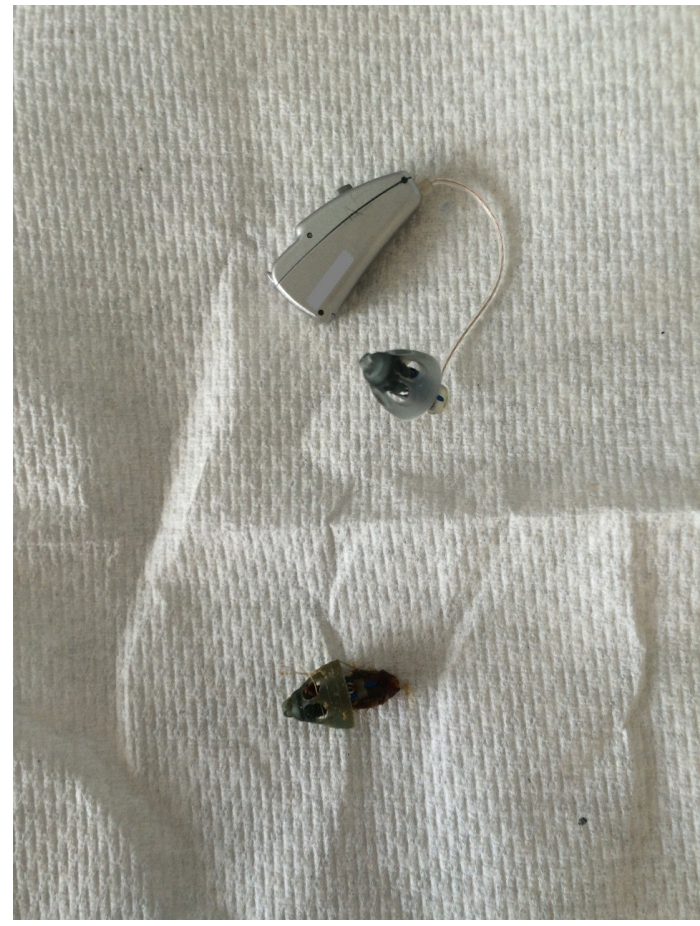

Figure 2 Foreign body removed next to hearing aid with a new plastic distal end.

with fullness in the left ear. On this occasion, there appeared to be a plastic foreign body in the external ear canal. The foreign body was removed whole with crocodile forceps. There was no resulting trauma to the ear canal.

The patient immediately recognised it as the end of his hearing aid (figure 1). Three months earlier, he had been on a cruise and felt like he had lost the end of his hearing aid (figure 1). He thought that this had fallen into the sea and on his return to the UK purchased a new one and had kept the original (figure 2).

The photographs show the end of the hearing aid with its original base (figures 1 and 2).

Despite there being reports of the moulding used to design hearing aids requiring surgical removal, ${ }^{3}$

\section{Learning points}

- Patients should always be reassessed fully after microsuction if they have not had adequate relief from the procedure. Preferably, this should occur within the same consultation.

- An iatrogenic foreign body should be a differential diagnosis in a patient who presents with changes in hearing and a foreign body sensation and wears hearing aids. 
there appear to be no case reports of the permanent plastic end of a hearing aid causing this particular problem.

In this case, the diagnosis was delayed due to several factors; primarily earwax obscuring the view coupled with a failure to take a full history of events. Finally, a hearing aid breaking and getting stuck in the external ear canal had not been considered by any of the clinicians managing this case.

Competing interests None declared.

Patient consent Obtained.
Provenance and peer review Not commissioned; externally peer reviewed.

(C) BMJ Publishing Group Ltd (unless otherwise stated in the text of the article) 2018. All rights reserved. No commercial use is permitted unless otherwise expressly granted.

\section{REFERENCES}

1 Thompson SK, Wein RO, Dutcher PO. External auditory canal foreign body removal: management practices and outcomes. Laryngoscope 2003;113:1912-5.

2 Balbani AP, Sanchez TG, Butugan O, et al. Ear and nose foreign body removal in children. Int J Pediatr Otorhinolaryngol 1998:46:37-42.

3 Kiskaddon RM, Sasaki CT. Middle ear foreign body. A hearing aid complication. Arch Otolaryngol 1983;109:778-9.

Copyright 2017 BMJ Publishing Group. All rights reserved. For permission to reuse any of this content visit http://group.bmj.com/group/rights-licensing/permissions.

BMJ Case Report Fellows may re-use this article for personal use and teaching without any further permission.

Become a Fellow of BMJ Case Reports today and you can:

- Submit as many cases as you like

- Enjoy fast sympathetic peer review and rapid publication of accepted articles

Access all the published articles

Re-use any of the published material for personal use and teaching without further permission

For information on Institutional Fellowships contact consortiasales@bmjgroup.com

Visit casereports.bmj.com for more articles like this and to become a Fellow 